\title{
Clinical Experience with Decompressive Craniectomy without Watertight Duraplasty
}

\author{
(1) Jülide Hazneci, (1D Ali Börekçi
}

Department of Neurosurgery, University of Health Sciences, İstanbul Fatih Sultan Mehmet Training and Research Hospital, İstanbul, Turkey

Submitted: 24.11.2020 Accepted: 13.12.2020

Correspondence: Jülide Hazneci, SBÜ, İstanbul Fatih Sultan Mehmet Eğitim ve Araştırma Hastanesi Beyin ve Sinir Cerrahisi Kliniği İstanbul, Turkey

E-mail: jhazneci3@hotmail.com

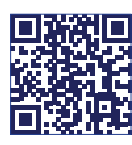

Keywords: Complication; decompressive craniectomy; duraplasty; watertight; without watertight.

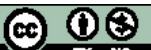

This work is licensed under Creative Commons Atribution-Non Commercil 40 Internationat

\begin{abstract}
Objective: This study was designed to determine the incidence of complications occurring after a decompressive craniectomy (DC) without duraplasty.
\end{abstract}

Methods: The data of 42 consecutive patients who underwent DC without watertight duraplasty were evaluated retrospectively and analyzed.

Results: The average age of the study group patients was 62.7 years (range: $34-90$ years) and 32 of the 42 patients of them were male. The mean Glasgow Coma Scale (GCS) score was 7 , the mean midline shift was $12.1 \mathrm{~mm}$, and the mean length of time from injury until DC was 1.9 days. Twenty-three patients were alive at least 20 days after DC. Antibiotherapy was used to treat a wound infection in $3(7.1 \%)$ patients. Two of these 3 patients were male and the mean age was 65.3 years. The mean GCS score before surgery in this subset of complicated cases was 7, the mean midline shift was $15 \mathrm{~mm}$, and the mean length of time until DC was 3.3 days. No other complications, such as brain abscess, meningitis, cerebrospinal fluid (CSF) fistula, or wound healing abnormalities were observed.

Conclusion: DC without watertight duraplasty had an acceptable incidence of postoperative complications. This technique reduces the surgical time of surgery, which can be vital in critical patients with malignant middle cerebral artery infarction or intracerebral hematoma.

\section{INTRODUCTION}

It is well known that intracranial hypertension refractory to treatment due to ischemic or hemorrhagic infarction is associated with significant morbidity and mortality. ${ }^{[1]}$ Urgent and appropriate surgery is critical for survival. ${ }^{[2]}$ A decompressive craniectomy (DC) was first described as a technique to manage posttraumatic cerebral swelling by Kocher in 1901. The cranial bone is removed and the surrounding dura are opened to allow the swollen brain to expand.

DC is a widely used and accepted neurosurgical procedure; however, dural closure following a craniectomy is still a matter of some debate. Some authors advise the use of watertight duraplasty in DC procedures to prevent complications, such as cerebrospinal fluid (CSF) fistula, infection, wound healing disturbance, or hygroma, ${ }^{[2,3]}$ while others maintain that rapid closure without watertight duraplasty is a safe and practical option with a comparable complication rate. ${ }^{[4-6]}$

This study is an investigation of complications occurring in patients who underwent DC without watertight duraplas- ty performed for intracerebral hemorrhage or malignant middle cerebral artery (MCA) infarction.

\section{MATERIALS AND METHODS}

Approval for the study was granted by the Clinical Research Ethics Committee of University of Health Sciences Fatih Sultan Mehmet Education and Research Hospital (2020/I26). Written consent was obtained from a first degree relative of all of the patients.

The data of 42 consecutive patients who were treated with DC for MCA infarction between April 2015 and May 2020 at a single neurosurgery clinic were evaluated retrospectively. Age, sex, medical history, cause of stroke, length of time until surgery, Glasgow Coma Scale (GCS) score at the time of surgery, and postoperative complications were recorded. The midline shift of the brain observed on computed tomography was also noted.

\section{Surgical technique}

In all cases, a large reverse question mark skin incision 

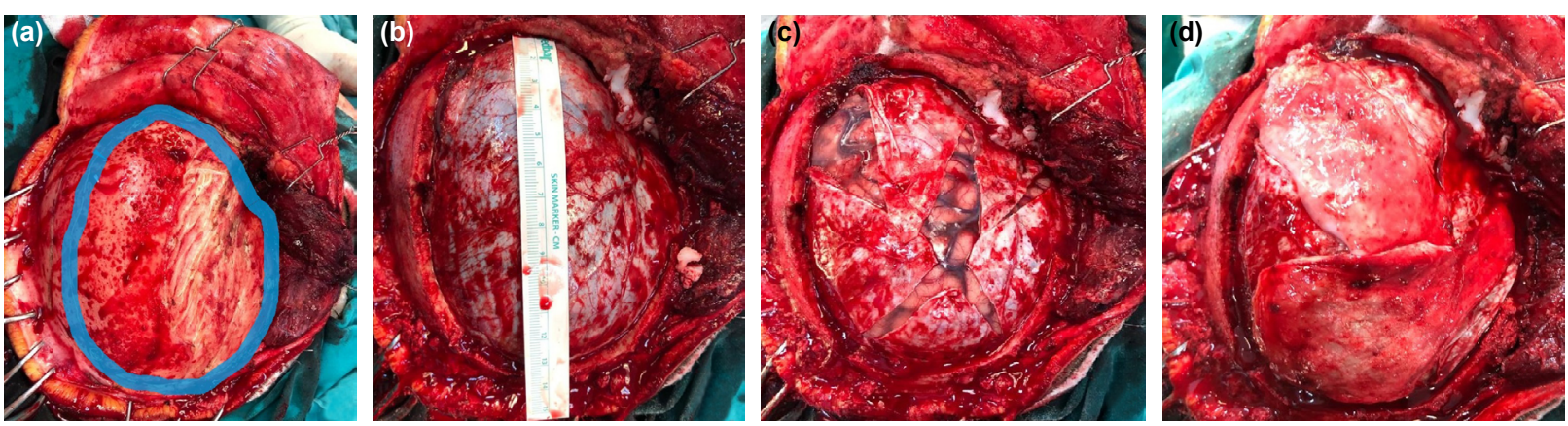

Figure 1. Intraoperative photographs demonstrating the surgical technique. (a) After the skin and the galea were elevated, the temporal muscle was dissected via interfascial dissection (the craniectomy borders are marked with the blue line); (b) A craniotomy at least $12 \times 12 \mathrm{~cm}$ wide was performed; (c) The dura was opened in a centripetal fashion; (d). The exposed brain parenchyma was covered with the pericranium.

from the tragus to the midline was performed. The skin and the galea aponeurotica were elevated. The temporal muscle was elevated via interfascial dissection (Fig. la). A craniotomy at least $12 \times 12 \mathrm{~cm}$ wide was performed and the temporal bone was removed until flush with the floor of the middle fossa (Fig. Ib). The dura was opened in a centripetal pattern (Fig. Ic), and the exposed brain parenchyma was then covered with the pericranium, and if needed, with a bovine pericardial patch (Fig. Id). Finally, the layers were replaced in appropriate anatomical planes.

\section{RESULTS}

A total of 42 patients with mean age of 62.7 years (range: 34-90 years), 32 of whom were male, were included in the study. The mean GCS score prior to surgery was 7 , the mean infarct volume was $217 \mathrm{cc}$, the mean midline shift was $12.1 \mathrm{~mm}$, and the mean length of time until DC was 1.9 days. Of the group, 23 patients were alive at least 20 days after DC. Three (7.I\%) patients developed a superficial wound infection, which was treated with antibiotherapy. Two of these patients with a wound infection were male, and the mean age was 65.3 years. The mean GCS score before surgery was 7 , the mean midline shift was $15 \mathrm{~mm}$, and the mean time until DC was 3.3 days in these 3 complicated cases. Other than the superficial wound infection detected in 3 patients, no complications, such as brain abscess, meningitis, CSF fistula, or wound healing disturbance, were recorded.

\section{DISCUSSION}

Since first recommended by Cushing in 1908, watertight duraplasty with an accurate approximation of the dural layers had been the accepted method used to prevent postoperative infection and CSF fistula. ${ }^{[7]}$ However, recent studies have demonstrated that non-watertight dural closure did not result in a higher incidence of complications. ${ }^{[4-6,8]}$ Primary watertight duraplasty requires some form of graft (pericranium, fascia lata or artificial) to provide a seal and prevent CSF fistula and infection.
Güresir et al. ${ }^{[5]}$ described a rapid-closure technique used in 318 patients who underwent DC for various reasons (traumatic brain injury, subarachnoid hemorrhage, intracerebral hematoma, cerebral infarction). Once the bone flap was removed, the dura was opened in a stellate fashion and duraplasty was not performed. The authors reported complications of wound healing disturbance in $3.5 \%$, abscess formation in $2.6 \%$, and CSF fistula in $0.6 \%$. They suggested that this rapid-closure technique without duraplasty was safe, feasible, and resulted in comparable or even lower complication rates than watertight duraplasty.

A randomized controlled study comparing watertight duraplasty and non-watertight duraplasty DC techniques yielded no statistically significant difference in the surgical complication rates. ${ }^{[4]}$ The results of this study also indicated that DC without watertight duraplasty was a safe procedure and not associated with a higher incidence of complications (CSF leak, wound infection, brain abscess or subgaleal fluid collection) when compared with watertight duraplasty.

Goedemans et al. ${ }^{\left[{ }^{9]}\right.}$ observed no complications in DC performed without watertight duraplasty in their study examining the association between the timing of $D C$ in patients with MCA infarction and the outcome. Alwadei et al. ${ }^{[6]}$ retrospectively compared the surgical results of supratentorial craniotomies with and without dural closure performed for different intracranial pathologies and reported infection in $1.8 \%$ and CSF fistula in $1.8 \%$ of patients in the open group (no duraplasty). They found no significant difference in the occurrence of CSF leak, infection, or surgical site swelling between the closed and open groups. The incidence of postcraniotomy headache was greater in the closed group.

In this study, 42 consecutive patients who underwent DC without watertight duraplasty for intracranial hypertension due to malignant MCA infarction or spontaneous intracerebral hematoma were retrospectively reviewed. We found the occurrence of a superficial wound infection treated with medication in $7.1 \%$ of the patients. No other complications, such as brain abscess, meningitis, CSF fistula, or wound healing disturbance were recorded. 


\section{CONCLUSION}

In this study, the only complication observed following DC without watertight duraplasty was an acceptable incidence of wound infection. A non-watertight duraplasty technique decreases the surgical time required, which can be vital in critical patients with a malignant MCA infarction or intracerebral hematoma. Furthermore, leakage of edematous brain tissue from weak points in the duraplasty has been reported in cases of watertight duraplasty. DC without watertight duraplasty appears to be a safe option with a comparable complication rate and the advantage of a shorter procedure.

Ethics Committee Approval

This study was approved by the Clinical Research Ethics Committee of Health Sciences University Fatih Sultan Mehmet Training and Research Hospital (2020//26).

Informed Consent

Retrospective study.

Peer-review

Internally peer-reviewed.

Authorship Contributions

Concept: J.H.; Design: J.H.; Supervision: J.H., A.B.; Materials: J.H.; Data: J.H., A.B.; Analysis: J.H., A.B.; Literature search: J.H.; Writing: J.H.; Critical revision: J.H.

Conflict of Interest

None declared.

\section{REFERENCES}

1. Moussa WM, Khedr W. Decompressive craniectomy and expansive duraplasty with evacuation of hypertensive intracerebral hematoma, a randomized controlled trial. Neurosurg Rev 2017;40:115-27.

2. Vahedi K, Hofmeijer J, Juettler E, Vicaut E, George B, Algra A, et al; DECIMAL, DESTINY, and HAMLET investigators. Early decompressive surgery in malignant infarction of the middle cerebral artery: a pooled analysis of three randomised controlled trials. Lancet Neurol 2007;6:215-22.

3. Aarabi B, Hesdorffer DC, Ahn ES, Aresco C, Scalea TM, Eisenberg $\mathrm{HM}$. Outcome following decompressive craniectomy for malignant swelling due to severe head injury. J Neurosurg 2006;104:469-79.

4. Vieira E, Guimarães TC, Faquini IV, Silva JL, Saboia T, Andrade RVCL, et al. Randomized controlled study comparing 2 surgical techniques for decompressive craniectomy: with watertight duraplasty and without watertight duraplasty. J Neurosurg 2018;129:1017-23.

5. Güresir E, Vatter H, Schuss P, Oszvald A, Raabe A, Seifert V, et al. Rapid closure technique in decompressive craniectomy. J Neurosurg 2011;114:954-60.

6. Alwadei A, Almubarak AO, Bafaquh M, Qoqandi O, Alobaid A, Alsubaie F, et al. Supratentorial craniotomies with or without dural closure-a comparison. World Neurosurg 2019;125:1132-7.

7. Cushing H. Surgery of the head. In: Keen WW, editor. Surgery, its principles and practice, vol III. Philadelphia: Saunders; 1908. p. 17276.

8. Barth M, Tuettenberg J, Thomé C, Weiss C, Vajkoczy P, Schmiedek P. Watertight dural closure: is it necessary? A prospective randomized trial in patients with supratentorial craniotomies. Neurosurgery 2008;63:352-8; discussion 358.

9. Goedemans T, Verbaan D, Coert BA, Kerklaan B, van den Berg R, Coutinho JM, et al. Outcome after decompressive craniectomy for middle cerebral artery infarction: timing of the intervention. Neurosurgery 2020;86:318-25.

\section{Su Geçirmez Duraplasti Yapılmayan Dekompresif Kraniektomi Olgularındaki Klinik Tecrübemiz}

Amaç: Bu çalışmanın amacı su geçirmez duraplasti yapılmayan dekompresif kraniektomi (DK) olgularında komplikasyon oranlarını tespit etmektir.

Gereç ve Yöntem: Kliniğimizde ameliyat edilen, 42 tane, su geçirmez duraplasti yapılmayan dekompresif kraniektomi olgusu geriye dönük olarak incelendi.

Bulgular: Çalışmaya alınan 42 hastanın ortalama yaşı 62.7 (34-90), 32'si erkekti. Hastaların başvuru anındaki Glasgow Koma Skalası (GKS) skoru ortalama 7 , ortalama orta hat şiftleri $12.1 \mathrm{~mm}$ ve DK yapılana kadar geçen süre ortalama 1.9 gün olarak tespit edildi. DK cerrahisi yapıldıktan en az 20 gün sonra hastaların 23 tanesi hayattaydı. Tüm hasta grubunda, toplam üç hastada (\%7.I) yüzeysel yara yeri enfeksiyonu tespit edildi. İkisi erkek olan bu üç hastanın ortalama yaşı 65.3 idi. Komplike olan üç olgunun başvuru anındaki GKS skoru ortalama 7, ortalama orta hat şiftleri ve DK yapılana kadar geçen süre ortalama 3.3 gün olarak tespit edildi. Olguların hiçbirinde beyin apsesi, menenjit, beyin omurilik sıvısı (BOS) fistülü ve/veya yara iyileşme problem görülmedi.

Sonuç: Sonuç olarak, su geçirmez duraplasti yapılmayan DK tekniği, yara yeri enfeksiyonları ve BOS fistülü gelişmesi açısından kabul edilebilir komplikasyon oranlarına sahiptir. Su geçirmez duraplasti yapılmayan DK tekniği, malign orta serebral arter enfartkı ve intraserebral hematom nedeniyle ameliyata alınan hastalarda çok hayati olan cerrahi süreyi kısaltmaktadır.

Anahtar Sözcükler: Dekompresif kraniektomi; duraplasti; komplikasyon; su geçirmez; su geçirmez olmayan. 